\title{
The Shirts of the Donso Hunters: materiality and power between concealment and visual display
}

DOI:

10.1017/asr.2017.152

\section{Document Version}

Accepted author manuscript

Link to publication record in Manchester Research Explorer

\section{Citation for published version (APA):}

Ferrarini, L. (2019). The Shirts of the Donso Hunters: materiality and power between concealment and visual display. African Studies Review, 62(1), 76-98. https://doi.org/10.1017/asr.2017.152

\section{Published in:}

African Studies Review

\section{Citing this paper}

Please note that where the full-text provided on Manchester Research Explorer is the Author Accepted Manuscript or Proof version this may differ from the final Published version. If citing, it is advised that you check and use the publisher's definitive version.

\section{General rights}

Copyright and moral rights for the publications made accessible in the Research Explorer are retained by the authors and/or other copyright owners and it is a condition of accessing publications that users recognise and abide by the legal requirements associated with these rights.

\section{Takedown policy}

If you believe that this document breaches copyright please refer to the University of Manchester's Takedown Procedures [http://man.ac.uk/04Y6Bo] or contact uml.scholarlycommunications@manchester.ac.uk providing relevant details, so we can investigate your claim.

\section{OPEN ACCESS}




\title{
The Shirts of the Donso Hunters: materiality and power between concealment and visual display
}

\section{Lorenzo Ferrarini}

Bio: Lorenzo Ferrarini is Lecturer in Visual Anthropology at the University of Manchester. He conducted research on donso hunters in Burkina Faso with a focus on the role of sensory perception and bodily ways of knowing in the practice of hunting. In addition to book chapters and journal articles, he is author of documentary films. Email: lorenzo.ferrarini@manchester.ac.uk

\begin{abstract}
This article looks at the characteristic shirts of the donso, or initiated Mande hunters. Often described in the literature as visual displays of the wearer's power, in the context of contemporary Burkina Faso these shirts are rather an example of how hunters deal with representations of power through an aesthetics of concealment (Ferme 2001). An excess of display is instead connected with the politics of state-recognized hunters' associations. In the practices and discourses on hunters' shirts intersect issues of ecological change, local conceptions of power and contemporary struggles with state authority.
\end{abstract}

Keywords: Burkina Faso, Clothing, Donsoya, Hunting, Materiality, Power, Secrecy, Visibility

In this article I examine contemporary practices and discourses surrounding the characteristic shirts of the donso, or initiated Mande hunters.[1] These clothes, a sort of uniform for this power association, allow an insight into conceptions of visual display and concealment that speak to the current relationship between hunters and power. The appearance of the hunters' shirts and of the items hung on them is a contested field that generates internal debates on the role of donso hunters in the current West African context, characterized by ecological transformations and 
political insecurity. Looking at these debates affords a window on these interrelated processes of transformation.

The hunters' shirt is an object that has a strong identity value and at the same time some very practical functions. As such, understanding this and other objects associated with performances of power requires supplementing a more traditional approach based on meaning by putting their materiality at the center. As I will argue, this is not just a way to address debates in the humanities and in particular in anthropology, where materiality has recently been reframed as a major force in social life, rather than a substrate for human signification and, more in general, culture (Appadurai 1986; Henare et al. 2007; Krmpotich et al. 2010; Miller 2005). A parallel debate, I found, is taking place among hunters as they discuss the relationship between their shirts and internal power hierarchies. For some hunters in contemporary Burkina Faso, the shirts paraded at gatherings and social occasions are a reflection of the wearer's prestige and power. Others reject this logic, refusing to treat the shirt as a transparent signifier of the status of the person wearing it. An analysis of this discussion allows to gain insights on the relationship between materiality and power, insights that go beyond the level of the regional ethnography.

Can we understand the role that these shirts play for donso hunters with a model that derives their power from a dualism between materiality and meaning? Treating them in other words as signifiers that express powerful meanings? I will argue that this model not only downplays the material aspects of the shirts and of their power, it does not adequately account for the processual and contested conditions from which performances of power emerge. Concentrating exclusively on materiality, on the other hand, would leave out of the frame the social dynamics whereby hunters' shirts and things in general acquire new roles and are at times treated as signs. But treating things as signs to be interpreted is not a neutral step in the process of analyzing their cultural meanings. It is a possibility emerging from the discourses that Webb Keane has called semiotic ideology (2005), referring to the set of conventions regarding what constitutes a sign and how signs are supposed to work. In other words, semiotic ideology is a historically specific metadiscourse on the status of signs.

Throughout this text I will approach the power of the shirt as primarily constituted by its materiality, rather than signified by it. This allows me to account for attempts to relocate its power in processes of signification as emerging from a historically specific semiotic ideology. This move is aimed at doing justice to the materiality of things, rather than treating it as a medium for representation, and at explaining the role things play in discursive practices, at the same time connecting 
these with the broader context. In fact, as will become clear in the rest of the article, in the politics of display surrounding hunters' shirts intersect issues of ecological change, local conceptions of power and contemporary struggles with state authority.

\section{The Shirts that Mande Hunters Wear}

In parts of Senegal, Mali, Guinea, Côte d'Ivoire and Burkina Faso, where hunting is typically a male activity, some men pursue a path of initiatory knowledge called donsoya. Being a donso is not entirely synonymous with being a hunter. Donsoya includes practical knowledge about killing game and initiatory knowledge that is only in part related to hunting. Donso hunters are often expert diviners, they prepare medicines with their vast knowledge of plants, and manipulate powerful objects such as amulets and fetishes. According to oral traditions, initiated hunters had important roles in the creation of medieval Mande state formations and constitute a remarkable example of interethnic power association whose membership transcends national borders (Cashion 1984; Cissé 1994; Traoré 2004).

During the last thirty years, the associative forms of donso hunters have undergone important changes, through the widespread constitution in staterecognized entities whose members are often employed as security guards, park rangers and even mercenaries (Bassett 2005; Ferme \& Hoffman 2004; Förster 2012; Hagberg 2004; Hellweg 2011; Leach 2004). These transformations are strictly connected to long-term processes of ecological change which for the hunters mean negotiating new and restrictive environmental laws and the disappearance of many types of prestigious game from the bush (Ferrarini 2016). As a result, donso identities are increasingly constructed, legitimized and performed away from hunting contexts and closer to urban spaces.

To a visitor who happened upon a donso parade in a West African town, the hunters in their characteristic shirts would likely result visually striking (figure 1). Being in fact oversized tunics sewn out of narrow strips of locally woven cotton, the shirts are dyed in vegetal and mud solutions that give them muted hues ranging from red to brown and yellow, often with black and grey/green motives. They swing around as the hunters dance, waving a number of objects attached to their outside surface. Some look like leather packages or bundles, others sport animal parts such as tufts of hair, horns, fangs or claws. Long strings of hide and knotted cotton threads hang from them, further complicating the visual appearance of the shirts. 
Figure 1. Donso hunters circling a burial site in Karankasso Sambla, Houet, Burkina Faso, April 2015.

In a classic article, Patrick McNaughton describes this visual clutter as an iconic reference to the hunters' privileged space, the intricate and wild bush, and at the same time to the moral ambiguity that surrounds their power (1982b). The busy and murky appearance of the shirts symbolizes dibi, the darkness associated with sorcery. Young or recently initiated hunters, he writes, start with a plain shirt and gradually build it up with objects they receive from their masters, more experienced hunters who transmit to them knowledge and talismans. As the apprentice hones his hunting skills he will kill more and more animals whose remains will start to appear on his shirt. A hunter's shirt then, in McNaughton's view, becomes a sort of curriculum vitae worn on the body where one can read the history and career of the wearer, "an index of the hunter's greatness" (1982b:57). To a knowledgeable onlooker, it would then be possible to roughly rank the hunters at a gathering on the basis of their clothing, distinguishing master hunters from novices and mid-career initiates. Significantly, McNaughton resorts to all three of Charles Sanders Peirce's (1932) categories of signs - icons, indexes and symbols - to describe the shirts, thus putting in the foreground their capacity to signify.

I would like to start from complicating this frame through the experience of my fieldwork in western Burkina Faso in 2011-12, which offers a different perspective. I will offer twofold insights on why this is the case: firstly, there is a difference in the approach and fieldwork methods that characterized my interactions with the hunters, and secondly a difference in time, whereby the more than thirty-five years between our respective fieldworks have seen important changes involving donsoya and its contexts. In contrast with previous studies, I centered my research on the skills (Grasseni 2007; Ingold 2000) and embodied knowledge (Harris 2007; Jackson 1983; Weiss \& Haber 1999) that donso hunters acquire as part of their apprenticeship.

Further, apprenticeship was for me both a focal interest and a methodological device, through my own initiation in donsoya and intensive practice of hunting. By becoming a member of the hunters' association of Karankasso Sambla, Houet, and a pupil of master hunter Adama Sogo Traoré from Samorogouan, Kénédougou, I tried to put in practice what Loïc Wacquant has called enactive ethnography: "immersive fieldwork through which the investigator acts out (elements of) the 
phenomenon in order to peel away the layers of its invisible properties and to test its operative mechanisms" (2015:5 emphasis in original). This involved a steep learning curve made of lengthy marches in the bush, gradual memorization of incantations and medicinal recipes, acquisition of amulets and power objects, but also included constituting my personal hunting shirt (locally donsodileke, McNaughton spells donsondloki in 1982:54). So, in a way, my perspective is enriched by the experience of having worn the shirt on the hunt and at gatherings, having sought and received amulets to hang on it, and having gradually developed it as my hunting skills and achievements progressed. Naturally, though, I am not basing what follows exclusively on my experiences but also on conversations with fellow students and teachers, plus numerous hunters met at ceremonies and gatherings in the course of my fieldwork.

Having in mind what McNaughton had written, it was surprising for me to see the hunting outfit my teacher Adama wore to participate to ceremonies and gatherings. Characterized by dark green vegetal motives on a pale brown fabric, combined with epaulettes and tapered trousers, the shirt had a military appearance. This style of pattern, achieved by stamping fermented mud on vegetal tinted cloth with a small acacia branch that had the compound leaves removed, is common in the westernmost regions of Burkina Faso (especially Kénédougou and Léraba. See figure 2). Remarkably, in a region where the dyeing of bogolanfini is typically the task and art of women (Brett-Smith 2014; Donne 1973; Imperato \& Shamir 1970), I only saw men handle the fabric of donso shirts. Since donsoya is such a markedly masculine domain, it is generally accepted that women should not come in contact with a hunter's outfit. [2]

Figure 2. Lacole Traoré dyeing a donso outfit, Samorogouan, Kénédougou, Burkina Faso, May 2012.

Crucially, Adama's shirt usually sports no more than two or three objects, neatly arranged on the loops designed for this purpose, on the upper chest. No visible threads or strips, no mirrors or general clutter on his shirt. Nevertheless, Adama is hardly a novice. Almost seventy years old as of the time of the research, he is known and recognized as one of the most knowledgeable and prestigious master hunters in the province of Kénédougou and beyond. A student of Tiefing Coulibaly of Dakoro (Hagberg 2004), the first national leader of the donso hunters of Burkina Faso, Adama counts on a network of allies and students that extends well beyond his natal town of Samorogouan to other regional centers of donsoya 
such as Ouolonkoto and Samoghohiri, without counting his relatives and associates in Mali and Côte d'Ivoire. In other words, Adama does not lack the experience, the relationship or the prestige to be considered a top-tier donso but his hunting shirt is relatively plain. Furthermore, Adama is not an isolated instance of master hunter sporting surprisingly low-key outfits, rather his way of approaching the furnishing of his shirt was shared among many of his high-ranking colleagues. In what follows I explore why this might be the case in the context of Burkina Faso in the 2010 s, basing on both the testimonies of the hunters and on broader observations conducted during fieldwork. The answer to this question is not just limited to the ethnographic context, rather it implies an understanding of the relationship between materiality and power that can be extended to other analyses of powerful objects on the African continent.

\section{The hunting shirt: materiality and the senses}

It is important to keep in mind that a donso shirt is first of all a garment born out of practical necessities. Ideally, a hunter will reserve a shirt for social occasions and a similar one for walking the bush with the shotgun. In fact, though, many of the hunters I met are not able to afford two shirts, whose locally woven fabric is significantly more expensive than imported printed cotton or synthetic fibers. As a result, they invest in a single shirt that has to cover for both situations. This will often lose its mud-died pattern due to exposure to the sun and soaking in sweat. The shotgun's sling will gradually wear the yoke to the point of tearing the fabric, and many hunters with whom I spent time would wear shirts whose original shape was barely recognizable.

These ragged shirts are not necessarily worn with embarrassment, rather their owners are somewhat proud of them. They are part of a discourse of authenticity that I will return to later, and remind other hunters that donsoya is a discipline fundamentally concerned with spending time in the bush. They remind non-hunters that the bush is not an easy place to be and its sun, rocks, thorns, and many dangers are hard on the hunters. The materials, colors and shape of the donso shirt suit the needs of the hunters: its thick cotton, for example, might seem overly warm at first sight but, as I found out for myself, withstands very well the many thorny bushes that one often ends up scrambling into. Initially, I had tended to leave my donsodileke at home, privileging lighter, fresher cotton clothing, but had to retrace my steps after coming back from the bush with my shirts torn up by the thorns that would painfully prick my arms. The heavier donso shirt, on the other hand, offered way more protection and resistance. Its numerous and large pockets were ideal to 
stuff the small game that we would hunt on most days - hares, francolins and other birds, hedgehogs, or giant pouched rats. Smaller pockets and loops offered storage for shotgun shells, medicinal powders and amulets. I was the only one to use a small backpack, but most of the hunters with whom I went searching for game carried everything they needed for one or more days in their shirts.

While visually the sun and the dust enhance the camouflaging qualities of the shirt, turning it of the same color as the bush during the dry season, this garment also has important auditory qualities. Let us not forget that hunters all around the world, at least those who practice stalking, are one of the few categories of people who choose their clothes on the basis of how they sound, in addition to how they look. Donso hunters are no exception and their shirts are made nearly silent by the soft yarn that is woven into the fabric strips that make them up. Additionally, the characteristic trousers that with the shirts are usually part of a donso's outfit are slimmed down below the knee with buttons, to avoid any rubbing sound when walking during a stalk.

There is a parallel here between the scarcity of studies on what donso hunters do in the bush that I had identified as a point of departure for my research, and the lack of attention that the hunting shirt has received compared to the ceremonial shirt. While the latter might seem more fertile ground for anthropological analysis, allowing to touch on hierarchies, symbols, sorcery, religion, and history, I contend that paying attention to the hunting shirt also allows insights on important aspects of donso sociality, provided these are understood to include transspecies forms of sociality (Haraway 2008; Kohn 2007; Nadasdy 2007) and engagements with environments and materials (Ingold 2007; Tilley 2004). The shirt can be framed similarly to a tool (Gibson \& Ingold 1993) and become one of the interfaces mediating hunters' interactions with the bush environment, its features referring to ecological engagements as knowledge-in-practice (Eden \& Bear 2011). In my own work (Ferrarini 2014) I have explored how hunters form an aesthetic community, a group sharing perceptual patterns (Cox 2002; Goldstein 1995; Meyer \& Verrips 2008), based on the control and discernment of sound. The hunters' sensibility to sound highlights their connection to the bush as an acoustic environment where one's capacity for suppressing sound is in direct connection with the capacity to perceive sound. The shirt's materiality, its fabric, shape and accessories directly connect to the quality of the interactions that hunters have with the bush. Its discolored, dirty, blood-stained and sometimes burned and ragged appearance echoes the sometimes self-indulging rhetoric about heroically enduring hardships that I heard in Adama's tales about hunting in the days of his youth and in informal conversations between hunters. This kind of rhetoric is also present in donso epics, 
and Karim Traoré has termed it an "aesthetics of suffering" (see also Kedzierska 2006:50-52; 2000:94, 186-192).

The material, sensuous experience of hunting in the bush - in which vision is just one among other sensory modalities - shapes the shirt and forms the basis for connecting it to the discursive levels of narrative and rhetoric. The shirt is not so much a representation of the bush, then, as it is a product of specific ways of human interaction with that environment. In this sense the shirt is so much more than a material sign to be read by other humans in a context of semiotic representation. Conversely, most studies of clothing use during the 1980s had their main focus on dress codes as ways to signify belonging in social interactions (Barthes 1983; Lurie 1981). Only later did anthropologists of materiality, building on explorations of dress as "situated bodily practice" (Entwistle 2000), use embodiment as an approach to frame clothes as intersection of sensual, affective, gendered and identity factors (Küchler \& Miller 2005; Woodward 2007).

McNaughton mentions hunting shirts only in passing and then dedicates the rest of his article to ceremonial shirts (1982b:56). As an art historian, he was concerned with those shirts that were deemed worthy of introduction into museum or private African art collections, which in the case of the donso hunters seem to correspond to the most adorned ones. If we take a look at the photographs that appear in his text, it is interesting to remark how in two informal portraits his informants wear simple, practical outfits, just fitted with a whistle and a knife. The other two images he selected, though, are still life shots from private collections, and represent extremely complex and busy shirts of the kind that he describes in writing. The photographs represent well how the everyday, in its utilitarian plainness, is treated with a documentary approach, whereas the more exceptional shirts are elevated to the status of art objects. The material, sensory, affective, and phenomenal qualities of the hunting shirts - and many other cultural artifacts - have traditionally been given a secondary status by museum curators, in favor of visual appearance and the potential to "read" cultural meanings (Edwards et al. 2006). That the most meaningful shirts are those with the most visual complexity is a principle against which I argue throughout this text, on the basis of local practices of display of power that are not in direct correlation with visual appearance. The tendency to privilege the visual is, instead, typical of the Western conception of the museum as a way of knowing, in which objects are deprived of their context of use and put on display for visual consumption (Alpers 1991; Mitchell 1988). As such, it speaks more of McNaughton's approach and background than it does of Mande practices of power. 
The two aspects of emphasizing the shirts' semiotic functions and privileging their visual features over the sensuous, material qualities are then interconnected and lead to missing important aspects in the everyday practices of donso hunters. But in my view it is also necessary to approach differently the powerful objects that are hung on these garments.

\section{The powerful shirt: materiality and concealment}

While hunters do not want on their hunting shirts too much material that could slow them down and make them noisy, even the practical and no-nonsense outfits are enhanced by a few amulets or talismans (figure 3). In most cases these will be targeted to the dangers related to the hunting activity: talismans against snakes or scorpions, or against accidents such as being shot by a companion or injured by a misfiring gun. Other objects are meant to enhance the chances of killing, as in the case of the kisen tilennan (literally "ball straightener") or of the fereke, a charm taking its name from the word that activates it ("trip!" or, more literally, "tangle up!"), designed to prevent an animal from running away. Some hunters will carry a variety of small, portable fetishes that will enable them to approach animals more easily, and that they can reward on the spot with the blood of the prey they just killed. Well hidden in their pockets, the fetishes of the donso hunters are smaller versions of power objects that are diffused throughout Mande Africa (Brett-Smith 1983; Colleyn 2004; Kedzierska-Manzon 2013). They are held capable of interacting with humans if addressed and rewarded with the right procedures, and constitute a form of highly specialized gendered knowledge (Royer 1996:253), which is normally surrounded by discretion.

Figure 3. Closeup of the author's hunting shirt after ten months of apprenticeship, including whistle, amulets and a bundle of rope.

On the other hand, the function of objects on ceremonial shirts is more likely to be that of shielding the wearer from sorcery attacks by colleagues. Related objects may be tasked with increasing the appeal of the carrier or preventing poisoning. In other words, most of the objects on a ceremonial shirt address relationships between hunters, instead of being finalized at hunting. The social occasions in which a number of hunters from an area gather together are potentially tense situations, as described by Hellweg (2011:Chapter 8). Musicians, through their praise, put some hunters in the spotlight and provoke them to promise 
that they will accomplish hunting feats that will increment their prestige, if they succeed - or ruin it, if they fail. Internal hierarchies are renegotiated as each hunter brings the results of his hunting expeditions to share with his fellow hunters. I heard numerous stories of sorcery attacks motivated by jealousy in such occasions. In a similar way to what happens for excessively proud or arrogant verbal statements, excessive adornment in these occasions can lead to aggression. The Jula term used by the hunters in the area where I worked is korobo, which is very significant because it means to test somebody, but literally it is composed of "revealing (bo) the underneath (koro)." The expression points at a consciousness of the presence of layers, and references the idea of going beneath somebody's surface to prove his real worth. The metaphorical aspect here is paralleled by a general principle whereby the most powerful object one carries will be hidden from sight, sometimes literally under the external layer of the shirt.

All of the above objects, be them related to hunting or to deal with other hunters, have in common a simple thing: they are chosen and placed on the shirt primarily for their function, and not for their visual appearance. This is an important point to underline, especially because it helps make sense of those objects that are not meant to be seen, but still empower the wearer through their presence. In this sense, there is more to a donso shirt than meets the eye. Not only does a hunter wear a number of amulets under his clothes, in contact with the skin, but some are sewn into the fabric of the shirt so that they become an invisible part of it. Brett-Smith also reports of how the tassels at the extremities of a donso shirt are tied with knots and incantations are recited on them, so that power is imbued in the fibers themselves (2001:122-23). Unlike the knotted threads that can be hung on it, these tassels are integral part of the shirt and do not necessarily advertise themselves as charms.

These practices remind us of how throughout the Mande area people deal with power through what Mariane Ferme called an "aesthetics of concealment" (2001), whereby a dialectic of knowledge and secrecy produces powerful persons. As in the case of the Poro association mask on the cover of Ferme's book (taken from Bravmann 1983), whose internal surface hides powerful Arabic inscriptions, the hunters' tunic draws some of its power from the contact between a body and things hidden within the shirt. This is particularly evident when hunters, like other seekers of knowledge in the area, make use of amulets and charms based on Quranic scripts. These can be in the form of folded up paper, often together with an activating substance and wrapped with cotton thread, then sewn in leather pouches that are worn on the body, hung on the shirts or kept in pockets (locally called seben, see Mommersteeg 1990). Another related use of Arabic and Quranic 
scripts is the repeated washing of the ink used to write on wooden tablets, whose resulting liquid (locally called nasi or nesi) is then used for medicinal purposes, to wash the body or impregnate objects (Bledsoe \& Robey 1986; Ferme 2001:16668; Marchand 2009:201-2). In both practices, it is interesting to remark how the function of writing of becoming a material carrier of power has the upper hand on the more predictable function of carrying meaning. This power, generally referred to with the term of Arabic origin barika and deriving from the Quranic provenance of the texts, is materialized through a process of hiding, be it as sewing in leather, liquefying, spitting as saliva or burying in the ground.

These materials carrying power, instead of semiotic meaning, are representative of the way a hunter's shirt is only partially meant to be a display of initiatory knowledge. From this point of view donso hunters conform to a wider regional trend that characterizes carefully hinting at the possession of knowledge as a wise, reasonable means of gaining prestige and influence (Piot 1993). In my experience of apprenticing in donsoya, master hunters were especially skilled at balancing the limited display of their knowledge with the promise of sharing it with the students, or in other words they were masters of the "paradox of secrecy" (Bellman 1981). Adama for example was able to juggle the appropriate distribution of occasional incantations and medicinal recipes to his cohort of students, which counted almost thirty members at very different levels of seniority of initiation, while at the same time being very careful in keeping us in a relationship of dependence from him for certain indispensible rituals and medicines. In other words, through giving and hinting at knowledge he was able to keep us interested and motivated but was careful to make sure that we could not make without him (more details in Ferrarini 2016:87-89). Ferme's use of the expression "concealment" is here very appropriate, for me, because it points at the act of hiding, which can of course be noticed and give away that there is something hidden. The term often used locally is gundo which, rather than being equated to secret in the dictionary acceptation of the term, is better translated as restricted access knowledge (Jansen 2000:106). The parsimonious distribution of knowledge is strongly characterized in gendered terms, being one of the main attributes of ceya, manhood. An unregulated flow of knowledge is instead associated with femininity, and is often used as an explanation of the exclusion of women from donsoya and other power associations (Leach 2000:583). Initiated hunters, from this point of view in similar ways to the members of other power associations, negotiate their power through a balance of display and concealment.

Given the practices outlined above, I find McNaughton's approach to donso shirts as a display of power problematic, especially because he shows awareness of 
these dynamics of concealment in his work on blacksmiths and on the Komo power association $(1979,1982 \mathrm{a}, 1987)$. Not only does he underestimate the sensory and affective qualities of the garment, privileging its visible meanings, but downplays the pragmatic functions of the complex shirt-amulets. To the practitioners of donsoya, their power derives from the materiality of the shirt and of the objects that with it constitute a complex whole. For them the primary functions of the shirt-amulets complex is not one of communicating or representing, but of enabling, empowering, and protecting. These powers are sometimes in direct conflict with visibility, as demonstrated above. Considering power as based on materiality, rather than signified by it, allows to make sense of concealment, because it allows power to be independent from social recognition in the absence of acts of representation.

Having clarified how much of the power of a donso shirt is independent from signification, I move now to analyze how social and ecological changes in the years between McNaughton's fieldwork and mine have reconfigured practices of concealment and display among donso hunters, creating a debate on whether shirts can be representations of the status of the wearer. In other words, I will trace the emergence inside Burkinabe donsoya of semiotic ideologies that treat the shirt an expression of power and explain what conditions have favored their appearance.

\section{The ceremonial shirt: materiality and change}

Why would a respected master hunter like Adama wear a relatively plain hunting shirt at ceremonies and gatherings? Listening to his many tales of sorcery duels dramatically carried out around gatherings of hunters, he does not seem to be scared of attracting malevolent attentions. Adama is, in my experience, very conscious of his aspect and is very proud of his masterfully dyed shirt, whose contrasty lines clearly show that he can afford not to use it for hunting. On the other hand, he wears very few items on it (figure 4). He does this purposefully, and comments negatively on those hunters who, on the other hand, choose not to keep a low profile. Like other hunters of his generation Adama associates an excess of display with donsoya as practiced within the associative forms that have transformed initiatory hunting in Burkina Faso during the past twenty years. For this newer incarnation they use the term donsotòn, using the suffix -tòn that is used for most associations with voluntary membership, also to underline how it does not entirely correspond to donsoya, which is the body of knowledge and practices of the donso (or literally being a donso, donso-ness). 
Figure 4. Adama Sogo Traoré posing in front of his house in Nyawali, Kénédougou, Burkina Faso, August 2012.

Donso hunters started to seek state recognition through formally constituted associations in the neighboring countries of Mali during the 1980s and later in Côte d'Ivoire (Cashion 1984:101-3; Hellweg 2011). Originally created to negotiate less restrictive hunting regulations and permits, these early associations took up the jargon of environmentalism to obtain state support. The urban civil servants who in many cases were behind their creation promised enlisting hunters as a sort of native forest guards, at times involving foreign funders by playing with the trope of the ecologically noble savage (Leach 2000:577-86). But their environmentalist agenda had put in motion processes that soon went beyond the original plans. Hunters' associations were very soon converting to enforcing security in situations where the state was absent, or constituting into militias (Bassett 2003; Hellweg 2009, 2011:45-51). Somewhat later than it happened in the two bordering countries, Burkina Faso saw the spread of modern associations from the mid-1990s. The idea, modalities and even the name of the association (Benkadi) were imported from Côte d'Ivoire by one of Adama's own mentors, Tiefing Coulibaly. He used existing networks among donso hunters to spread new initiation procedures, a simplified form of admission that allowed young men to receive a membership card and status of donso hunter with the payment of a small fee and a simple sacrifice. This "fast-track" access to donsoya contrasted with the lengthy process of apprenticeship whereby a man who sought membership had to patiently prove himself worthy to a master hunter for up to seven years before he could be initiated (Hagberg 2006:782). Tiefing Coulibaly's move overlapped and confused membership into an association with initiation, and created scores of young hunters for whom both the esoteric dimension of knowledge and the hunting-related skills were secondary to the local authority warranted by the association card and donso shirt. The new associative form spread quickly in western Burkina Faso, where Benkadi became a movement marked by ethnic opposition between the farmers who constituted its membership base and Fulani herders and Mossi farmers, perceived as foreign invaders and thieves (Hagberg 1998, 2006).

The impact of these new dynamics cannot be overestimated. In Burkina, as elsewhere, hunters' associations changed donsoya into a wider movement less rooted in solitary hunting activities in the bush and more concerned with apprehending delinquents. As the new associations started to gain recognition by the state, their internal micro-politics became more entwined with party politics. It 
is fairly common today to see donso hunters being mobilized to campaign for a politician, taking advantage of their popularity among rural populations. A case in point was the struggle over the succession to Tiefing Coulibaly after his death, and the presence of politicians at this funeral (Hagberg 2004:63-65). This process is not peculiar of Burkina Faso, but is a general trend of the other countries where donsoya is present (Bassett 2003; Förster 2012; Jansen 2008).

Many of the master hunters belonging to the older generations with whom I discussed these trends expressed themselves in negative terms about the way the donsoya of the associations is distancing itself more and more from what they perceive as core values: dedication, stoic endurance of the hardships of the bush, thirst for knowledge, integrity, respect for the elders. Bakari Sanou of Kouakoualé, a master hunter well in his seventies when I visited him in his compound not far from Bobo Dioulasso, was very outspoken in denouncing how modern donsoya was for him all about politique, a term which he tellingly used in French. He referred to the behind-the-scenes negotiations for obtaining power that took place at meetings of hunters, and evocatively mocked the new, up-and-coming hunters by sticking his chest out and gesturing at the many ornaments on their shirts. Like Adama, who had been his hunting companion in the 1970s, he said that at gatherings and ceremonies he would sit in a corner, with his simple shirt, and leave the youngsters to their strutting around. The fool would dismiss him for his ordinary appearance, the wise would fear what he was not showing. His compound mirrored this philosophy, looking like the unremarkable home of an elderly farmer and his wives, yet politicians and football players would take the sandy dirt road to visit him and require the help of his power objects.

Similarly to Adama, for him a plain shirt with few amulets is a statement on the things he recognized as valuable in donsoya, it is a position against (relatively) new trends and associations. The way he treated visibility was a direct enactment of those values and a reference to times in which hunters were few and spent most of their time on the hunt. Most of all, he would never wear an association card: complete with ID photo and stamps, these badges were commonly seen during my fieldwork and were a way to signify loyalties in a time when two national associations were competing for the support of rural hunters. Hagberg gathered similar opinions from a master hunter of the Sidéradougou district, who comments on the de-coupling of the shirt from the hunting knowledge and activity among younger, card-carrying hunters: "They carry the hunting dress as a sign of adolescence, bravery [cameliya]. All carry the hunting dress, because they say it is an association. Formerly, if someone carried this dress, there was something going on in the bush..." (quoted in Hagberg 2004:56). In the case of the Karaboro farmers 
dominating the hunting association examined by Hagberg, the hunting shirts had taken the explicitly visual function of intimidating other ethnic groups specifically Fulbe herders - and - especially combined with the association badge - of sanctioning the wearers' authority. This process, which derived from the new initiation procedures of Benkadi, weakened the links of the shirt with the bush and with the complex knowledge of donsoya.

Although there is a definite component of nostalgia in the discourses of these old master hunters, they were not alone in their statements and were trying to inculcate these values to their disciples. I experimented this firsthand when I was reprimanded for wearing too many objects on the front of my own shirt, especially considering my status of novice. However, as much as they insisted that internal hierarchies should be negotiated through hunting feats instead of being based on relationships between hunters, public speeches and client-patron dependencies, the changing ecological context made their appeals more and more unrealistic. For many younger hunters in today's Burkina Faso the prospect of killing the large animals that give prestige to a master hunter is made ever more unlikely by those same environmental laws that started the trend of state-recognized associations. In other words, if associations were progressively distancing hunters from the bush, it was in part because they were born out of reconfigured relationships with it. The prestigious game whose killing earned Adama or Bakari their fame is now protected with sanctions that are in most cases severely enforced. In other cases, for example with large antelopes or felines, the animal might be simply absent from the region, due to overhunting and reduction of its habitat. Killing that kind of game means then embarking in hunting expeditions that could mean a considerable financial investment and even take a hunter abroad.

For these reasons, the complex cycle of mutual influences between new associative forms and transforming ecology (Ferrarini 2016) makes the objects found - or absent - on a hunter's shirt more representative of his network of human relationships than of his engagements with hunted animal species. Whereas McNaughton seems to imply that the animal parts present on a donso shirt belonged to an animal killed by the wearer (1982b:57), in my experience of contemporary hunting in Burkina Faso this is rarely the case. First of all, animal matter is used as ingredient or container in the preparation of amulets, and its primary function is not that of displaying the wearer's prowess. Further, many amulets are made from parts of domestic animals, especially the horns of goats or rams, but also sometimes the hair of a black cat or the tail of a bull. Goat leather is often used for wrapping medicinal bundles, but I have seen some amulets sewn in reptile or fish skin, depending on the function of the object. When parts of a wild 
animal are used, it is often the case that the animal has been killed by somebody else, and the horns or fangs traded to a specialist who then crafted the object. Not only are animal parts traded using student-master networks or in market stalls, but finished amulets can be given to a deserving disciple or inherited from a relative. It becomes then harder to claim that animals parts hanging from the shirts make "obvious reference to the creatures from which they have been detached, and to the powers of the bush" (McNaughton 1982b:58). McNaughton remarks that the most elaborate shirts were becoming rare at the time of his fieldwork (1982b:56), but I would claim that in contemporary Burkina this is less a consequence of a lack of dedication to hunting than it is an index of the quality and size of a hunter's network of human relationships.

Figure 5. Diakalia Traoré posing in front of his house, Fon, Kénédougou, Burkina Faso, August 2012.

Significantly, among donso hunters the category whose tunics corresponds to McNaughton's description of complex shirts is that of accomplished musicians (figure 5). Literally covered in amulets, mirrors, hide strips, knotted threads, Quranic talismans, and animal parts, donso musicians are also one of the central hubs in the networks of exchanges of knowledge and material objects among hunters. They are sometimes called donsojeli but unlike griots they do not constitute an endogamous socio-professional group. They are instead initiated hunters who have specialized in the music-making activity, which in most cases replaces hunting for them. They play repertoires and musical instruments that, although related to other musical genres, are specific of donso hunters (Bird 1972; Charry 2000:Chapter 2; Traoré 2000). The musician is a key figure in the public sanction of the internal hierarchy among donso hunters. His praises during funerals, annual sacrifices or other gatherings of hunters make public the exploits of a donso in the presence of his peers. The musician can receive money in exchange, often dropped in the sound hole of his instrument. Theoretically though, as I heard many times in Burkina, he should praise the hunter after receiving a share of the meat of the killed animal (traditionally the shoulder, see also Hellweg 2011:82). The bond between a hunter and his musician should not then be mediated by money, which resonates with the critiques I often heard voiced against musicians who insistently praised wealthy hunters - not necessarily the most skilled. The idea here is not that praising should not be rewarded, but rather that rewards can be of different kinds than money: a powerful master hunter can reveal 
medicinal recipes, give an amulet, tell an incantation, share an Arabic script endowed with power or promise meat. A popular donso musician becomes then a nodal point in a network of master hunters, receiving knowledge from a multitude of sources in a shorter time than it would take for an apprentice to travel around and gain the trust of some teachers. Musicians invest a big part of their knowledge in gaining magical means that help them to be more popular and liked - such as dawulafla, medicines for gaining charm. The flipside of this exposure is the possibility of arousing jealousy and sorcery attacks, especially from colleagues. A musician's shirt, then, is a striking exhibition of knowledge in the way it is cluttered with amulets, demonstrating its owner's prestige as much as it works to protect him. Its workings are explicitly visual, as underlined by the many mirrors on it. However, while it is possible to roughly measure the level of accomplishment of a musician from his shirt, the items he has on it are not so much directly representative of his hunting or occult skills but, indirectly, of his ability to take advantage of networks of knowledgeable hunters.

\section{Conclusions}

Donsoya went through important changes in the lapse between the place and time in which McNaughton's fieldwork took place - Mali in the 1970s, when associations were not yet diffused - and the circumstances of my own research. Some of McNaughton's characterizations of hunters as individualistic and antisocial actors in Mande society $(1982 \mathrm{~b}: 55,1988: 71)$ seem to have been supplanted by a different paradigm of networked donso, who carefully tends to the micro-politics of associations and through them deals with state actors such as politicians and forest guards. The wilderness, traditionally the center of hunting activities and source of power and knowledge, is becoming less important in comparison to the urban manifestations of donsoya and the workings of modern associations. The literature on Mande hunters in the past thirty years tells the story of various stages of reconfigurations in the relationships between hunters, between them and their environment, and between forms of authority. The practices and discourses around hunters' shirts reflect a struggle over changing values, in which the ways of understanding display are the subject of disagreement between traditionalists and exponents of associations. The line brought forward by traditionalists such as Adama or Bakari is that the shirt is not a sign, and that it does not represent the power of its wearer. They are not treating it as epiphenomenal, though, replicating a typically Western between the superficial appearances of clothes and the deeper substance of the inner self. Rather they practice a more complex relationship between the shirt and the power of the 
wearer, centered on concealment and a "dialectic of extraordinary visible effects caused by powerful hidden means" (Murphy 1998:563). Importantly, those same amulets and talismans would likely not have been an issue had we not been in a time of associations, ecological crisis, and spread of donsoya among unskilled youths. In this sense, Adama or Bakari's low key outfits also have a performative character, in their oppositional stance, that perhaps goes beyond their wearer's intentions.

Today's donso shirts in Burkina Faso are also shaped by the changing ecology, the availability of animals or the possibilities of hunting them. Here the political ecology of hunting reconfigures the hierarchies of hunters, for example when my teacher Adama gets fined and threatened of imprisonment for having killed a hippopotamus with the wrong permit, in occasion of his mother's funeral. The young president of an emergent hunters' association, on the other hand, with the right political connections and the skills to maneuver inside the bureaucracy of the Burkinabe state, gets to pull the trigger on a hippo while accompanied by forest guards. In such a reconfigured scenario, where killing great animals is not anymore a matter of initiatory knowledge or hunting skills, we need to look at the shirts of the donso hunters with different eyes. They also tell us about donsoya's relationships with the state, as paramilitary uniforms that allow to carry a gun, through the exhibition of association cards or as expressions of support to a political candidate.

Even recognizing these contextual changes, I have proposed a different, more nuanced approach to visibility. I am critical of an approach to hunters' shirts as primarily displays of amulets and animal parts. Such an ocularcentric approach downplays functions beyond that of signifying, such as the practical uses of the shirts and the material power of its objects. In this respect, I have underlined the importance of materiality vis-à-vis the semiotic, while still recognizing that both dimensions coexist and function in making hunters' shirts what they are. In general, while I argue that language should not constitute the model for analyzing material objects, things in general, and specifically clothes, offer the potential to be understood as primarily material or primarily semiotic. Which aspect will take the upper hand depends on contextual factors such as circumstances of use and broader political or ideological discourses. A struggle between hunters is taking place at the level of creating the conditions for the establishment of dominant semiotic ideologies, which enable the treatment as signs or the resignification of existing objects. Similar processes even invest masks and power objects brought on parade for independence ceremonies under rebel domination in northern Côte d'Ivoire, which come to stand for the forces behind national unity (Förster 2012:49-51). 
The struggle for power is located on the same meta-level, it is also a struggle for whose semiotic ideology will become predominant and not simply confined to acts of signification.

\section{References}

Allman, Jean Marie, ed. 2004. Fashioning Africa: Power and the Politics of Dress. Bloomington, IN: Indiana University Press.

Alpers, Svetlana. 1991. "The Museum as a Way of Seeing.” Pp. 25-32 in Exhibiting Culture: The Poetics and Politics of Museum Display, edited by I. Karp and S. D. Lavine. Washington: Smithsonian Institution Press.

Appadurai, Arjun, ed. 1986. The Social Life of Things: Commodities in Cultural Perspective. Cambridge University Press.

Barthes, Roland. 1983. The Fashion System. New York: Hill and Wang.

Bassett, Thomas J. 2003. "Dangerous Pursuits: Hunter Associations (Donzo Ton) and National Politics in Cote d'Ivoire." Africa 73:1-30.

—. 2005. "Card-Carrying Hunters, Rural Poverty, and Wildlife Decline in Northern Cote d'Ivoire." Geographical Journal 171:24-35.

Bellman, Beryl L. 1981. "The Paradox of Secrecy.” Human Studies 4:1-24.

Bird, Charles S. 1972. "Heroic Songs of the Mande Hunters." Pp. 274-94 in African folklore, edited by R. M. Dorson. Bloomington: Indiana University Press.

Bledsoe, Caroline H. and Kenneth M. Robey. 1986. "Arabic Literacy and Secrecy among the Mende of Sierra-Leone." Man 21:202-26.

Bravmann, René A. 1983. African Islam. Washington DC, London: Smithsonian Institution Press; Ethnographica.

Brett-Smith, Sarah C. 1983. "The Poisonous Child." RES: Anthropology and Aesthetics (6):47-64.

- 2001. "When Is an Object Finished? The Creation of the Invisible among the Bamana of Mali." RES: Anthropology and Aesthetics (39):102-36. 
Cashion, Gerald A. 1984. "Hunters of the Mande: A Behavioral Code and Worldview Derived from the Study of Their Folklore." PhD Thesis, Indiana University, Bloomington.

Charry, Eric. 2000. Mande Music: Traditional and Modern Music of the Maninka and Mandinka of Western Africa. University of Chicago Press.

Cissé, Youssouf. 1994. La confrérie des chasseurs Malinké et Bambara: mythes, rites et récits initiatiques. Ivry, Paris: Editions Nouvelles du Sud; Association ARSAN.

Colleyn, Jean-Paul. 2004. “L'alliance, le dieu, l'objet.” L'Homme (170):61-77.

Cox, Rupert A. 2002. The Zen Arts: An Anthropological Study of the Culture of Aesthetics Form in Japan. London: Routledge Curzon.

Donne, J. B. 1973. "Bogolanfini: A Mud-Painted Cloth from Mali.” Man 8(1):104-7.

Eden, Sally and Christopher Bear. 2011. "Reading the River through 'watercraft': Environmental Engagement through Knowledge and Practice in Freshwater Angling." Cultural Geographies 18(3):297-314.

Edwards, Elizabeth, Chris Gosden, and Ruth B. Phillips. 2006. "Introduction." Pp. 131 in Sensible Objects: Colonialism, Museums and Material Culture, edited by E. Edwards, C. Gosden, and R. B. Phillips. Oxford; New York: Berg.

Entwistle, Joanne. 2000. The Fashioned Body: Fashion, Dress, and Modern Social Theory. Cambridge; Malden, MA: Polity Press; Blackwell.

Ferme, Mariane C. 2001. The underneath of Things: Violence, History, and the Everyday in Sierra Leone. Berkeley; London: University of California Press.

Ferme, Mariane C. and Danny Hoffman. 2004. "Hunter Militias and the International Human Rights Discourse in Sierra Leone and beyond.” Africa Today 50:7395.

Ferrarini, Lorenzo. 2014. "Ways of Knowing Donsoya: Environment, Embodiment and Perception among the Hunters of Burkina Faso." PhD Thesis, University of Manchester, Manchester. Retrieved January 5, 2016 (https://www.escholar.manchester.ac.uk/uk-ac-man-scw:227214).

. 2016. "The Dankun Network: The Donso Hunters of Burkina Faso between Ecological Change and New Associations." Journal of Contemporary African Studies 34(1):80-96.

Förster, Till. 2012. "Imagining the Nation: Independence Ceremonies under Rebel Domination in Northern Côte d'Ivoire." African Arts 45(3):42-55.

Gibson, Kathleen R. and Tim Ingold. 1993. Tools, Language and Cognition in Human Evolution. Cambridge University Press. 
Goldstein, Judith L. 1995. "The Female Aesthetic Community." Pp. 310-29 in The traffic in culture: refiguring art and anthropology, edited by G. E. Marcus and F. R. Myers. Berkeley: University of California Press.

Grasseni, Cristina. 2007. Skilled Visions: Between Apprenticeship and Standards. New York: Berghahn Books.

Hagberg, Sten. 1998. Between Peace and Justice: Dispute Settlement between Karaboro Agriculturalists and Fulbe Agro-Pastoralists in Burkina Faso. Uppsala: Acta Universitatis Upsaliensis.

_ 2004. "Political Decentralization and Traditional Leadership in the Benkadi Hunters' Association in Western Burkina Faso.” Africa Today 50:51-70.

- 2006. "'It Was Satan That Took the People': The Making of Public Authority in Burkina Faso." Development and Change 37:779-97.

Hansen, Karen Tranberg and D.Soyini Madison, eds. 2013. African Dress: Fashion, Agency, Performance. London and New York: Bloomsbury Academic.

Haraway, Donna J. 2008. When Species Meet. Minneapolis: University of Minnesota Press.

Harris, Mark, ed. 2007. Ways of Knowing: Anthropological Approaches to Crafting Experience and Knowledge. New York and Oxford: Berghahn Books.

Hellweg, Joseph. 2009. "Hunters, Ritual, and Freedom: Dozo Sacrifice as a Technology of the Self in the Benkadi Movement of Cote d'Ivoire." Journal of the Royal Anthropological Institute 15:36-56.

- 2011. Hunting the Ethical State: The Benkadi Movement of Cote d'Ivoire. Chicago and London: University of Chicago Press.

Henare, Amiria J. M., Martin Holbraad, and Sari Wastell, eds. 2007. Thinking through Things. London: UCL.

Imperato, Pascal James and Marli Shamir. 1970. "Bokolanfini: Mud Cloth of the Bamana of Mali." African Arts 3(4):32-80.

Ingold, Tim. 2000. The Perception of the Environment: Essays on Livelihood, Dwelling and Skill. London: Routledge. . 2007. “Materials against Materiality.” Archaeological Dialogues 1(14):1-16.

Jackson, Michael. 1983. "Knowledge of the Body.” Man 18:327-45.

Jansen, Jan. 2000. "The Mande Magical Mystery Tour - the Mission Griaule in Kangaba (Mali)." Mande Studies Mande Studies (2):97-114.

. 2008. "From Guild to Rotary: Hunters' Associations and Mali's Search for a Civil Society." International Review of Social History 53:249-70. 
Keane, Webb. 2005. "Signs Are Not the Garb of Meaning: On the Social Analysis of Material Things." Pp. 182-205 in Materiality, edited by D. Miller. Durham, N.C.: Duke University Press.

Kedzierska, Agnieszka. 2006. "De la violence et de la maîtrise: habitus et idéologie cynégétiques mandingues." Thèse de doctorat, INALCO, Paris.

Kedzierska-Manzon, Agnès. 2013. "Humans and Things: Mande 'Fetishes' as Subjects." Anthropological Quarterly 86(4):1119-51.

Kohn, Eduardo. 2007. "How Dogs Dream: Amazonian Natures and the Politics of Transspecies Engagement." American Ethnologist 34(1):3-24.

Krmpotich, Cara, Joost Fontein, and John Harries. 2010. "The Substance of Bones: The Emotive Materiality and Affective Presence of Human Remains." Journal of Material Culture 15(4):371-84.

Küchler, Susanne and Daniel Miller, eds. 2005. Clothing as Material Culture. Oxford; New York: Berg.

Leach, Melissa. 2000. "New Shapes to Shift: War, Parks and the Hunting Person in Modern West Africa." Journal of the Royal Anthropological Institute 6:57795 .

— 2004. "Introduction to Special Issue: Security, Socioecology, Polity: Mande Hunters, Civil Society, and Nation-States in Contemporary West Africa." Africa Today 50:vii-xvi.

Lurie, Alison. 1981. The Language of Clothes. New York: Random House.

Marchand, Trevor. 2009. The Masons of Djenné. Bloomington, IN: Indiana University Press.

McNaughton, Patrick R. 1979. Secret Sculptures of Komo : Art and Power in Bamana (Bambara) Initiation Associations. Philadelphia: Institute for the Study of Human Issues.

—. 1982a. "Language, Art, Secrecy and Power: The Semantics of Dalilu." Anthropological Linguistics 24(4):487-505.

—. 1982b. "The Shirts That Mande Hunters Wear.” African Arts 15:54-58 \& 91.

- 1987. "Nyamakalaw - the Mande Bards and Blacksmiths." Word \& Image 3:271-88.

- 1988. The Mande Blacksmiths: Knowledge, Power, and Art in West Africa. Bloomington: Indiana University Press.

Meyer, B. and J. Verrips. 2008. "Aesthetics.” P. xv, 240 p. in Key words in religion, media and culture, edited by D. Morgan. New York, NY; London: Routledge.

Miller, Daniel, ed. 2005. Materiality. Durham, N.C.: Duke University Press. 
Mitchell, Timothy. 1988. Colonising Egypt. Berkeley and Los Angeles: University of California Press.

Mommersteeg, Geert. 1990. “Allah's Words as Amulet.” Etnofoor 3(1):63-76.

Murphy, William P. 1998. "The Sublime Dance of Mende Politics: An African Aesthetic of Charismatic Power." American Ethnologist 25(4):563-82.

Nadasdy, Paul. 2007. "The Gift in the Animal: The Ontology of Hunting and HumanAnimal Sociality." American Ethnologist 34:25-43.

Peirce, Charles Sanders. 1932. Collected Papers of Charles Sanders Peirce. edited by C. Hartshorne and P. Weiss. Cambridge, MA: Harvard University Press.

Piot, C. D. 1993. "Secrecy, Ambiguity, and the Everyday in Kabre Culture." American Anthropologist 95:353-70.

Royer, Patrick. 1996. "In Pursuit of Tradition: Local Cults and Religious Conversion among the Sambla of Burkina Faso." University of Illinois, UrbanaChampaign.

Tilley, Christopher. 2004. The Materiality of Stone: Explorations in Landscape Phenomenology. Oxford: Berg.

Traoré, Karim. 2000. Le jeu et le sérieux: essai d'anthropologie littéraire sur la poésie épique des chasseurs du Mande (Afrique de l'Ouest). Köln: R. Köppe.

. 2004. "The Intellectuals and the Hunters: Reflections on the conference 'La Rencontre Des Chasseurs de I'Afrique de I'Ouest.'” Africa Today 50:97-111.

Wacquant, Loïc. 2015. "For a Sociology of Flesh and Blood." Qualitative Sociology 38(1):1-11.

Weiss, Gail and Honi Fern Haber, eds. 1999. Perspectives on Embodiment the Intersections of Nature and Culture. New York: Routledge.

Woodward, Sophie. 2007. Why Women Wear What They Wear. New York: Berg.

\section{Notes}

[1] Alternative spellings of the term donso are known in the literature, for example dozo, donzo, dosso. The spelling dozo, in particular, is increasingly used in Burkina Faso in the context of contemporary associations, in part due to the influence in this field of Ivorian donsoya, where this spelling is more common. I will stick to the spelling donso because I consider it a more faithful representation of the way the word is pronounced in the area where I did research.

[2] But as most literature on African dress reminds us, most items associated with tradition actually emerge from long histories of regional or transnational contact and 
processes of invention (Allman 2004; Hansen \& Madison 2013). In the case of donso shirts there is a clear absorption of features of military provenance that has a likely long history. During my fieldwork I witnessed the delivery of a batch of hunting suites printed with the usual leaf motif on robust polycotton fabric. 